\title{
OPTIMISATION OF SOLID STATE FERMENTATION OF BANANA PEELS FOR CITRIC ACID PRODUCTION
}

\author{
N. A. Amenaghawon ${ }^{1, *}, 0$. Oiwoh $^{2}$ and 0. E. Ebewele ${ }^{3}$ \\ 1,2,3 Department of Chemical Engineering, University of Benin, PMB 1154, Benin City, Edo State, NiGERIA. \\ Email addresses:1andrew.amenaghawon@uniben.edu, ${ }^{2}$ okieaghughuese@yahoo.com, \\ 3eboseremen.ebewele@uniben.edu
}

\begin{abstract}
In this study, design of experiment (DOE) for response surface methodology (RSM) was used to analyse and optimise the simultaneous effect of solid substrate loading, initial $\mathrm{pH}$ and inoculum density on citric acid production from banana peels via solid state fermentation using Aspergillus niger. A three-variable, three-level Box-Behnken design was used to develop a statistical model to describe the relationship between citric acid concentration and the chosen independent variables and to optimise the production of citric acid using RSM. The model was statistically significant $(p<0.0001)$ with a low standard deviation $(0.43)$ and did not show lack of fit $\left(R^{2}=0.999\right)$. Citric acid production was significant at high levels of solid loading, low levels of $\mathrm{pH}$ and intermediate levels of inoculum density. Solid loading positively influenced citric acid production while the reverse was the case for initial pH. The optimum values of solid loading, $\mathrm{pH}$ and inoculum density were $20 \mathrm{~g} / \mathrm{L}, 8$ and $4.97 \times 10^{6} \mathrm{spores} / \mathrm{mL}$ respectively. Under these conditions, the citric acid concentration was obtained as $49.9 \mathrm{~g} / \mathrm{L}$. Validation of the statistical model showed an insignificant difference between experimental and model predicted results.
\end{abstract}

Keywords: Optimisation, Citric acid, Banana peels, Aspergillus niger, Solid state fermentation

\section{INTRODUCTION}

Citric acid is a tricarboxylic acid that is utilised in a wide range of industries. It is an important microbial product used in the food and beverage industries as an acidifying, flavouring, preserving, chelating and buffering agent and also in other industries such as in the production of pharmaceuticals, cosmetics and textiles [1-3]. The use of citric acid in the food and beverage industry accounts for about $7 \%$ of the total citric acid produced annually while its use in the pharmaceutical and other industries account for $12 \%$ and $18 \%$ respectively $[4,5]$. As a result of the high cost associated with chemical synthesis of citric acid, the biotechnological route via submerged fermentation using Aspergillus niger has been favoured [6].

Recently, a lot of research work has been done on solid state fermentation (SSF) with the view to adopting it as an alternative to submerged fermentation [2, 3, 6-10]. Solid state fermentation has some important advantages when compared with submerged fermentation. It has a higher citric acid yield, lower energy and water requirements, less risk of bacterial contamination, less wastewater generation and less environmental concern regarding the disposal of solid waste [5]. By adopting SSF, solid waste materials such as abundantly available and cheap agricultural wastes such as sugarcane bagasse $[7,8]$, apple pomace [9], banana peels [4], date palm [10], carob pod [11], grape pomace [12] can be used for the sustainable production of citric acid.

Banana peel is an example of a solid substrate that can be used for SSF. Nigeria is the fourth largest producer of banana in sub-Saharan Africa [13]. The processing of banana into products such as chips, puree/pulp, powder, jams, juice, bar, biscuits, wine etc results in the generation of solid banana wastes particularly the peels which account for about $40 \%$ of the total weight of the fresh banana fruit [14]. These wastes do not have any important use apart from being used as animal feed. Furthermore, they are typically disposed of inappropriately particularly in less developed countries thereby contributing to environmental problems [15]. As the waste material is rich in carbohydrate and other nutrients, it can serve as an 
ideal substrate for citric acid production via solid state fermentation [16].

The production of citric acid has been reported to be influenced by fermentation conditions such as type and composition of fermentation medium, substrate type and concentration, agitation rate, aeration, temperature, $\mathrm{pH}$ etc $[2,17,18]$. The performance of the SSF process can be significantly improved if these conditions are optimised. Experimental design methods coupled with response surface methodology (RSM) have been reported to be very effective in achieving this and it has been successfully applied to the optimisation of many bioprocesses $[19,20]$. Hence the objective of this study was to optimise the fermentation conditions for the production of citric acid from banana peels using Aspergillus niger in batch reactor. A three variable Box-Behnken design for response surface methodology was used to study the simultaneous effect of three independent variables (solids loading, $\mathrm{pH}$ and inoculum density) for optimum citric acid production.

\section{MATERIALS AND METHODS}

\subsection{Feedstock Preparation}

Banana peels were obtained from a local market in Benin City, Edo State, Nigeria and used as solid carbon substrate in this study. The chemical composition of banana peels has been previously reported in a study by Anhwange et al. [16] as shown in Table 1. The peels were washed with clean water to remove any adhering dirt after which they were dried in an oven at $60^{\circ} \mathrm{C}$ for 2 hours. The dried peels were then milled to obtain $2 \mathrm{~mm}$ particles.

Table 1: chemical composition of banana peels [16]

\begin{tabular}{lc}
\hline Component & Composition (wt \%) \\
\hline Carbohydrate & 59.0 \\
Protein & 0.9 \\
Crude fibre & 21.7 \\
Phytate & 0.28 \\
Crude lipid & 1.7 \\
Ash & 8.5 \\
Moisture & 6.7 \\
\hline
\end{tabular}

\subsection{Microorganism and Inoculum Preparation}

Aspergillus niger ATCC 9142, obtained from the Biotechnology division of the Federal Institute of Industrial Research Oshodi (FIIRO), Lagos, Nigeria was used throughout the study as the fermenting organism. Conidia suspensions of fungal strains were obtained from cultures grown on potato dextrose agar slants at $30^{\circ} \mathrm{C}$ for 5 to 7 days. The spores were washed with sterilised $0.8 \%$ Tween 80 solution by shaking vigorously for 1 minute. Spores were counted with a haemocytometer to obtain the desired number of spores [2].

\subsection{Solid State Fermentation}

Solid state fermentation was carried out in $250 \mathrm{~mL}$ Erlenmeyer flasks with a working volume of $100 \mathrm{~mL}$. The solid substrate was weighed into the flask and to this a supplemental salt solution was added to achieve the desired moisture level. The composition of the salt solution was as follows (g/L): $\mathrm{MgSO}_{4} \cdot 7 \mathrm{H}_{2} \mathrm{O}: 0.15$; $\mathrm{CaCl}_{2}: 0.015 ; \quad \mathrm{ZnSO}_{4} \cdot 7 \mathrm{H}_{2} \mathrm{O}: 0.002 ; \quad \mathrm{MnSO}_{4} \cdot \mathrm{H}_{2} \mathrm{O}: 0.006$; $\mathrm{FeCl}_{3} \cdot 6 \mathrm{H}_{2} \mathrm{O}: 0015$. Yeast extract was taken as nitrogen source. The contents were thoroughly mixed, cotton plugged and autoclaved at $121^{\circ} \mathrm{C}(15 \mathrm{psi})$ for $20 \mathrm{~min}$ [3]. After cooling, the sterilised substrate including media was inoculated with $2 \mathrm{~mL}$ of inoculum and then incubated at varying conditions in a rotary shaking incubator for 5 days. The solid substrate loading, $\mathrm{pH}$ and the inoculum density were varied according to the experimental design. At the end of fermentation, the medium was diluted with distilled water $(1: 4 \mathrm{w} / \mathrm{v})$ and then filtered and the filtrate was used for analysis [4].

\subsection{Analytical Methods}

The concentration of citric acid produced during fermentation was determined using the pyridineacetic anhydride method as reported by Marrier and Boulet [21]. This was accomplished by adding $1 \mathrm{~mL}$ of the filtered fermentation broth along with $1.30 \mathrm{~mL}$ of pyridine and $5.7 \mathrm{~mL}$ of acetic anhydride in a test tube. The test tube was then placed in a water bath at $32{ }^{\circ} \mathrm{C}$ for $30 \mathrm{~min}$. The absorbance of the sample was measured at $405 \mathrm{~nm}$ using a UV-Vis spectrophotometer (PG Instruments model T70). The concentration of citric acid in the sample was determined from a citric acid calibration curve which was prepared from known concentrations of citric acid. The $\mathrm{pH}$ of the sample was determined using a Unican 9450 model pH meter [2].

\subsection{Experimental Design}

A three variable Box-Behnken design (BBD) for response surface methodology was used to develop a statistical model to describe the production of citric acid from banana peels. The range of the variables that were optimised is shown in Table 2. The Box-Behnken design is suitable for the exploration of quadratic 
response surfaces and this design can be used to develop a second degree polynomial model which can be utilised for optimisation purposes [17]. The number of experimental run for this design is obtained from Equation (1).

$$
N=k^{2}+k+c_{p}
$$

Where $k$ is the number of factors and $c_{p}$ is the number of replications at the center point. The experimental design was developed using Design Expert ${ }^{\circledR}$ 7.0.0 (Stat-ease, Inc. Minneapolis, USA). The coded and actual values of the independent variables were calculated using Equation (2).

$$
X_{i}=\frac{X_{i}-X_{o}}{\Delta X_{i}}
$$

Where $x_{i}$ and $X_{i}$ are the coded and actual values of the independent variable respectively. $X_{o}$ is the actual value of the independent variable at the center point and $\Delta X_{i}$ is the step change of $X_{i}$.

Table 2: Experimental range and level of the independent variables

\begin{tabular}{ccccc}
\hline \multirow{2}{*}{ Variables } & Symbol & \multicolumn{3}{c}{ Coded Levels } \\
\cline { 3 - 5 } & & -1 & 0 & +1 \\
\hline $\begin{array}{c}\text { Solids loading } \\
(\mathrm{g} / \mathrm{L}) \\
\mathrm{pH}\end{array}$ & $\mathrm{X}_{1}$ & 5 & 12.5 & 20 \\
$\begin{array}{c}\text { Inoculum } \\
\text { density }\end{array}$ & $\mathrm{X}_{2}$ & 2 & 5 & 8 \\
\hline
\end{tabular}

The following generalised second order polynomial equation was used to estimate the response of the dependent variable [22].

$$
Y_{1}=b_{o}+\sum b_{i} X_{i}+\sum b_{i j} X_{i} X_{j}+\sum b_{i i} X_{i}^{e}+e_{i}
$$

Where $Y_{i}$ is the dependent variable or predicted response, $X_{i}$ and $X_{j}$ are the independent variables, $b_{o}$ is offset term, $b_{i}$ and $b_{i j}$ are the single and interaction effect coefficients and $e_{i}$ is the error term. The Design Expert software was used for regression and graphical analysis of the experimental data. The goodness of fit of the model for citric acid production was evaluated by the coefficient of determination $\left(\mathrm{R}^{2}\right)$ and analysis of variance (ANOVA). The optimum values of the variables tested were obtained by numerical optimisation based on the criterion of desirability [23].

\section{RESULTS AND DISCUSSION}

\subsection{Statistical Analysis}

Table 3 shows the result of the 17 experimental runs carried out according to the BBD. Multiple regression analysis was applied to the experimental data to obtain Equation (4) which was used to estimate the response (citric acid concentration).

$$
\begin{aligned}
y=90.70-4.71 & X_{1}-1.8 .69 X_{2}-0.38 X_{3}+0.53 X_{1} X_{2} \\
& +0.12 X_{1} X_{3}+0.51 X_{2} X_{3}+0.12 X_{1}^{2} \\
& +0.89 X_{2}^{2}-0.62 X_{3}^{2}
\end{aligned}
$$

The values of citric acid concentration predicted by Equation (4) are also shown in Table 2 along with the

\begin{tabular}{|c|c|c|c|c|c|c|c|}
\hline \multirow{3}{*}{ Run no } & \multicolumn{6}{|c|}{ Factors } & \multirow{3}{*}{$\begin{array}{l}\text { Response } \\
\begin{array}{l}\text { Citric acid } \\
\text { conc. (g/L) }\end{array} \\
\text { Observed }\end{array}$} \\
\hline & \multicolumn{3}{|c|}{ Coded values } & \multicolumn{3}{|c|}{ Actual values } & \\
\hline & $\mathrm{X}_{1}$ & $\mathrm{X}_{2}$ & $\mathrm{X}_{3}$ & $\mathrm{X}_{1}$ & $\mathrm{X}_{2}$ & $\mathrm{X}_{3}$ & \\
\hline 1 & -1 & -1 & 0 & 5 & 2 & 3.25 & 39.01 \\
\hline 2 & 1 & -1 & 0 & 20 & 2 & 3.25 & 33.71 \\
\hline 3 & -1 & 1 & 0 & 5 & 8 & 3.25 & 5.86 \\
\hline 4 & 1 & 1 & 0 & 20 & 8 & 3.25 & 48.12 \\
\hline 5 & -1 & 0 & -1 & 5 & 5 & 0.5 & 13.49 \\
\hline 6 & 1 & 0 & -1 & 20 & 5 & 0.5 & 26.30 \\
\hline 7 & -1 & 0 & 1 & 5 & 5 & 6 & 6.69 \\
\hline 8 & 1 & 0 & 1 & 20 & 5 & 6 & 29.52 \\
\hline 9 & 0 & -1 & -1 & 12.5 & 2 & 0.5 & 30.04 \\
\hline 10 & 0 & 1 & -1 & 12.5 & 8 & 0.5 & 12.72 \\
\hline 11 & 0 & -1 & 1 & 12.5 & 2 & 6 & 19.93 \\
\hline 12 & 0 & 1 & 1 & 12.5 & 8 & 6 & 19.43 \\
\hline 13 & 0 & 0 & 0 & 12.5 & 5 & 3.25 & 16.81 \\
\hline 14 & 0 & 0 & 0 & 12.5 & 5 & 3.25 & 17.72 \\
\hline 15 & 0 & 0 & 0 & 12.5 & 5 & 3.25 & 16.81 \\
\hline 16 & 0 & 0 & 0 & 12.5 & 5 & 3.25 & 17.72 \\
\hline 17 & 0 & 0 & 0 & 12.5 & 5 & 3.25 & 16.81 \\
\hline
\end{tabular}
experimental data. The significance of the fit of the citric acid model was assessed by performing analysis of variance (ANOVA).

Table 3: Box-Behnken design matrix for citric acid production

The model was statistically significant as seen from the very low $p$ value $(p<0.0001)$ as shown in Table 4 . The lack of fit $p$ value of 0.7346 indicates that the model did not show lack of fit. Results presented in Table 4 also show that all the model terms were significant as seen from their very low $\mathrm{p}$ values. Figure 1 is a parity plot showing a comparison between experimental values of the response and those predicted by the statistical model. The Figure shows that there was an acceptable level of correlation between the experimental and model predicted results. This is evident from the fact that the data points all clustered around the $45^{\circ}$ diagonal line showing that there was minimal deviation between 
experimental and predicted values thus indicating optimal fit of the model [3].

Table 5 shows the statistical information for ANOVA for the citric acid model. The model had a high coefficient of determination $\left(\mathrm{R}^{2}\right)$ which showed that it was able to adequately represent the relationship between the independent variables and the response (citric acid concentration). An $\mathrm{R}^{2}$ value of 0.999 means that $99.9 \%$ of the variability in the response could be explained by the model. A low standard deviation of 0.43 means that there was very little deviation of the individual values of the response from the mean. The coefficient of variation (CV) was obtained as 1.98. This value gives an indication of the degree of precision with which the treatments were carried out [24]. The relatively low value of $\mathrm{CV}$ obtained showed that the treatments were carried out with high precision and reliability [25]. The Adequate precision for the model was obtained as 126.52 showing that the model can be used to navigate the design space [26].

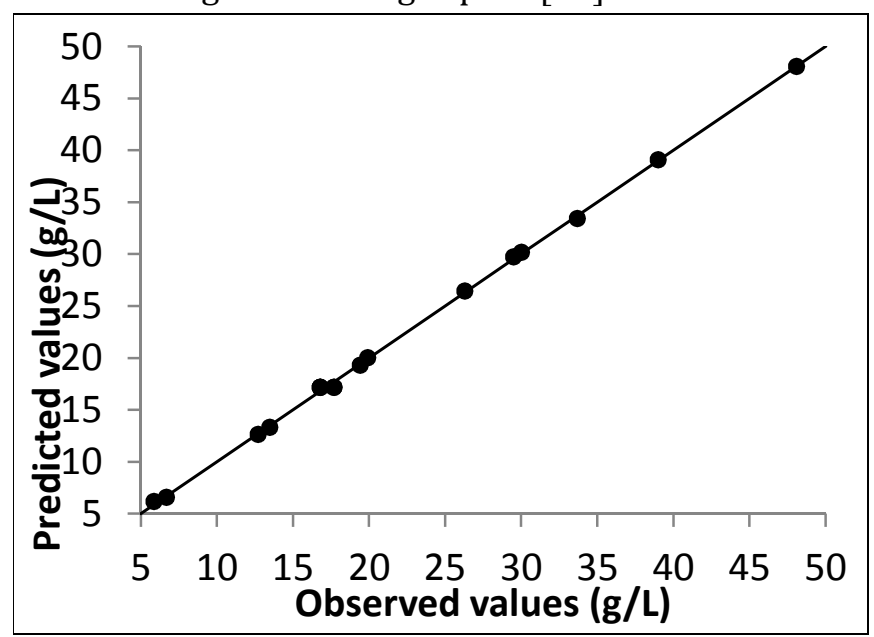

Figure 1: Parity plot showing comparison between experimental and predicted values

Table 4: ANOVA results for citric acid production model

\begin{tabular}{llllll}
\hline Source & $\begin{array}{l}\text { Sum of } \\
\text { Squares }\end{array}$ & df & $\begin{array}{l}\text { Mean } \\
\text { Square }\end{array}$ & F value & p value \\
\hline Model & 2027.87 & 9 & 225.32 & 1206.96 & $<0.0001$ \\
$X_{1}$ & 658.78 & 1 & 658.78 & 3528.89 & $<0.0001$ \\
$X_{2}$ & 167.04 & 1 & 167.04 & 894.77 & $<0.0001$ \\
$X_{3}$ & 6.09 & 1 & 6.09 & 32.62 & 0.0007 \\
$X_{1} X_{2}$ & 565.36 & 1 & 565.36 & 3028.44 & $<0.0001$ \\
$X_{1} X_{3}$ & 25.05 & 1 & 25.05 & 134.21 & $<0.0001$ \\
$X_{2} X_{3}$ & 70.70 & 1 & 70.70 & 378.69 & $<0.0001$ \\
$X_{12}$ & 177.13 & 1 & 177.13 & 948.82 & $<0.0001$ \\
$X_{2} 2$ & 270.50 & 1 & 270.50 & 1448.99 & $<0.0001$ \\
$X_{3} 2$ & 91.38 & 1 & 91.38 & 489.48 & $<0.0001$ \\
\hline Residual & 1.31 & 7 & 0.19 & & \\
Lack of Fit & 0.33 & 3 & 0.11 & 0.44 & 0.7346 \\
Pure Error & 0.98 & 4 & 0.25 & & \\
Cor Total & 2029.18 & 16 & & & \\
\hline
\end{tabular}

Table 5: Statistical information for ANOVA of citric acid model

\begin{tabular}{ll}
\hline Parameter & Response \\
\hline R-Squared & 0.999 \\
Adjusted R-Squared & 0.998 \\
Mean & 21.80 \\
Standard Deviation & 0.43 \\
C.V \% & 1.98 \\
Adeq. Precision & 126.52 \\
\hline
\end{tabular}

Table 6: Citric acid model coefficient estimate and confidence intervals

\begin{tabular}{lllllll}
\hline Factor & $\begin{array}{l}\text { Coefficient } \\
\text { Estimate }\end{array}$ & df & $\begin{array}{l}\text { Standard } \\
\text { Error }\end{array}$ & $\begin{array}{l}95 \% \mathrm{Cl} \\
\text { Low }\end{array}$ & $\begin{array}{l}95 \% \mathrm{Cl} \\
\text { High }\end{array}$ & VIF \\
\hline Intercept & 17.17 & 1 & 0.19 & 16.72 & 17.63 & \\
$\mathrm{X}_{1}$ & 9.07 & 1 & 0.15 & 8.71 & 9.44 & 1 \\
$\mathrm{X}_{2}$ & -4.57 & 1 & 0.15 & -4.93 & -4.21 & 1 \\
$\mathrm{X}_{3}$ & -0.87 & 1 & 0.15 & -1.23 & -0.51 & 1 \\
$\mathrm{X}_{1} \mathrm{X}_{2}$ & 11.89 & 1 & 0.22 & 11.38 & 12.40 & 1 \\
$\mathrm{X}_{1} \mathrm{X}_{3}$ & 2.50 & 1 & 0.22 & 1.99 & 3.01 & 1 \\
$\mathrm{X}_{2} \mathrm{X}_{3}$ & 4.20 & 1 & 0.22 & 3.69 & 4.71 & 1 \\
$\mathrm{X}_{12}$ & 6.49 & 1 & 0.21 & 5.99 & 6.98 & 1.01 \\
$\mathrm{X}_{2} 2$ & 8.02 & 1 & 0.21 & 7.52 & 8.51 & 1.01 \\
$\mathrm{X}_{3} 2$ & -4.66 & 1 & 0.21 & -5.16 & -4.16 & 1.01 \\
\hline
\end{tabular}

\subsection{Optimisation of Citric Acid Production}

Three dimensional (3D) response surface plots were generated to determine the optimum levels of the variables that were investigated in this study. The plots were generated by keeping one variable constant at the center point and varying the others within the experimental range. The resulting response surfaces showed the effect of solids loading, $\mathrm{pH}$ and inoculum density on citric acid production.

Figure 2 shows the effect of solid loading and $\mathrm{pH}$ on citric acid production. The trend observed indicates that citric acid production was favoured at high solids loading. This is evident from the increase in citric acid concentration when the solid loading was increased. The amount of solids used for solid state fermentation determines the amount of fermentable sugars that can be liberated for the purpose of producing citric acid. Since citric acid production is enhanced at increased sugar concentration, it will be expected that increasing the solid loading will also have a similar effect. The increase in citric acid concentration in the course of fermentation could be attributed to the consumption of sugar substrate by the Aspergillus niger cells to produce citric acid [7, 9]. These results are in agreement with those reported by previous 
researchers. Kim [27] reported a similar increase in citric acid concentration with increase in sugar substrate loading for the production of citric acid from peat moss. Al-Sheri and Mostafa [28] also reported a similar trend for the production of citric acid from date palm syrup using immobilized Aspergillusniger cells. The initial $\mathrm{pH}$ of the fermentation medium displayed a significant overall negative effect on citric acid concentration as shown in Figure 2. This is evident from the inverse relationship between the $\mathrm{pH}$ and the production of citric acid. This result is also corroborated by the negative value of the coefficient estimate of the model term representing $\mathrm{pH}$ (i.e. $\mathrm{X}_{2}$ ) as shown in Table 6. At low solid loading, citric acid production was observed to increase with a decrease in $\mathrm{pH}$. This observation could be attributed to the fact that a low $\mathrm{pH}$ is required to begin citric acid production. The low $\mathrm{pH}$ value also provides a sterile environment which reduces the risk of contamination as well as inhibiting the production of unwanted by products such as oxalic and gluconic acids which reduces citric acid yield [29]. With increasing solid loading, citric acid concentration was observed to increase with $\mathrm{pH}$. Maximum citric acid concentration was recorded at a pH of 8 and a solid loading of 20 g/L. Similar results have also been reported in the literature. Barrington and $\operatorname{Kim}[18]$ reported an optimum pH of 7.1 for the production of citric acid from peat moss. In another study, Ali et al. [30] reported an optimum $\mathrm{pH}$ of 6 for the production of citric acid from cane molasses in a stirred fermenter using Aspergillus niger.

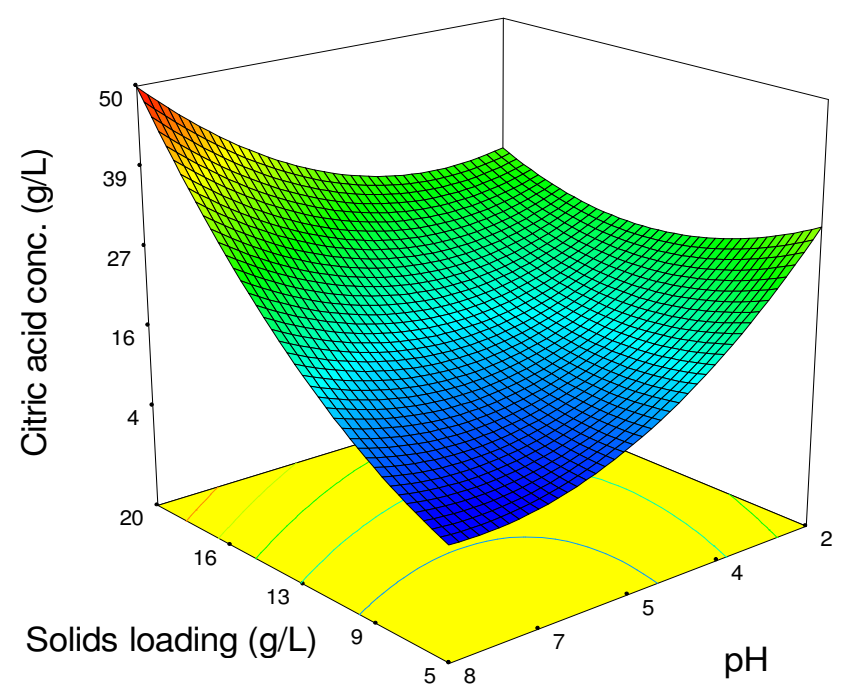

The interactive effect of inoculum density and initial $\mathrm{pH}$ on the fermentation process is shown in Figure 3. Inoculum density is an important fermentation variable that has been reported to affect citric acid production [31]. Citric acid production displayed a quadratic relationship with the inoculum density showing that the citric acid concentration increased with inoculum density up to a certain level beyond which any further increase in inoculum density did not positively affect citric acid production as shown in Figures 3 and 4. This observation has also been reported by previous researchers. According to Nampoothiriet al.[32], metabolite formation during fermentation generally increases with increase in inoculum density up to a particular limit. At low values of inoculum density, there is the risk of contamination as a result of insufficient microbial cell population and these results in a decline in the production of metabolic products [18]. A high inoculum density results in population over crowding which consequently results in increased competition for nutrients as well as rapid consumption of the nutrients [33]. Reports in the literature indicate that an inoculum density between $1 \times 10^{4}$ to $1 \times 10^{9}$ spores $/ \mathrm{mL}$ is typically favourable for citric acid production by Aspergillus niger [34]. The optimum inoculum density obtained in this study (i.e. $4.97 \times 10^{6}$ spores $/ \mathrm{mL}$ ) falls within this range thus corroborating the results obtained by previous researchers. The optimisation of the statistical model resulted in the selection of the optimum fermentation conditions and their respective levels. The maximum citric acid concentration predicted by the model was $49.9 \mathrm{~g} / \mathrm{L}$.

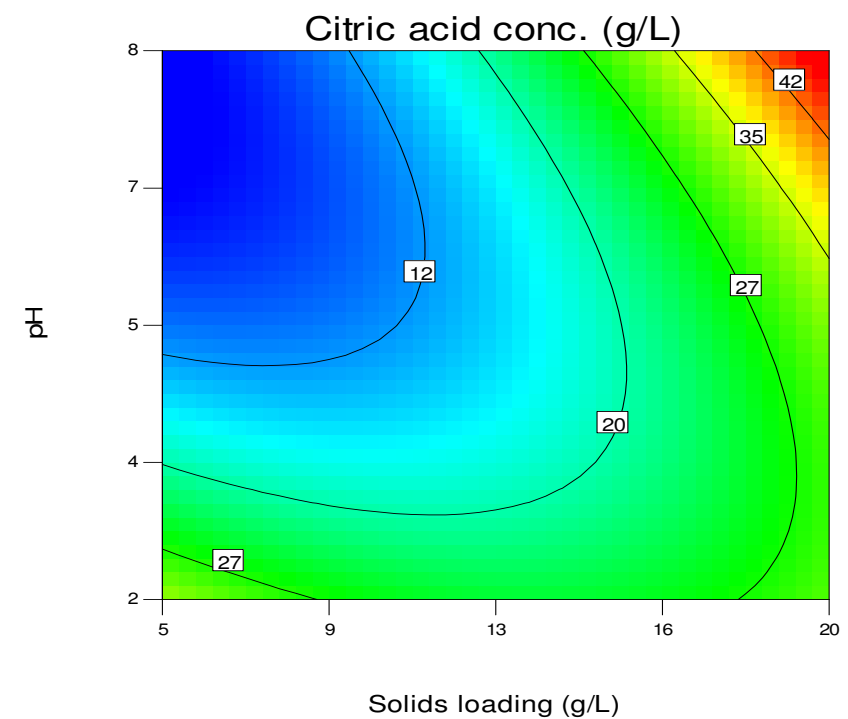

Figure 2: Response surface and corresponding contour plot showing the effects of solids loading and pH on citric acid concentration 

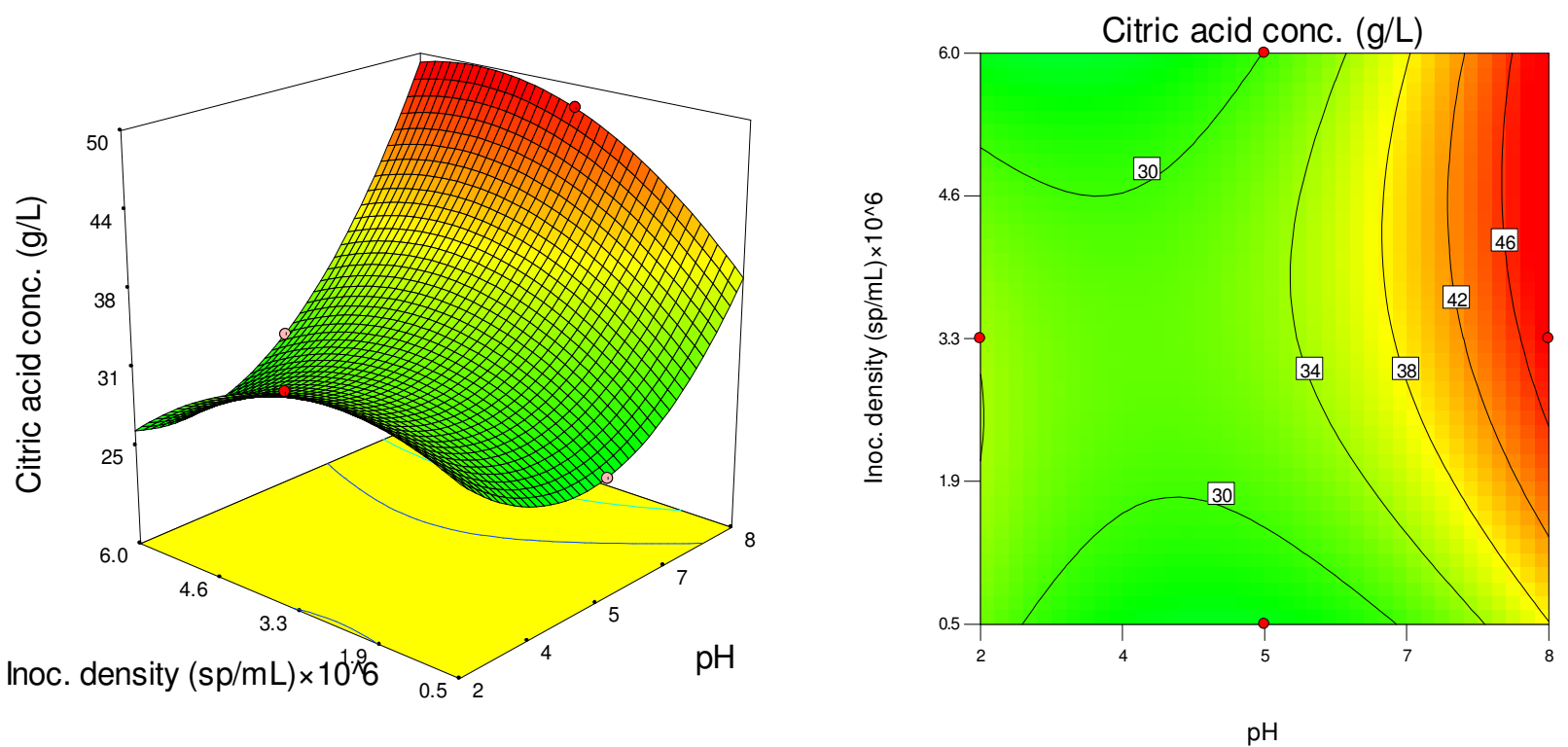

Figure 3: Response surface and corresponding contour plot showing the effects of inoculum density and pH on citric acid concentration
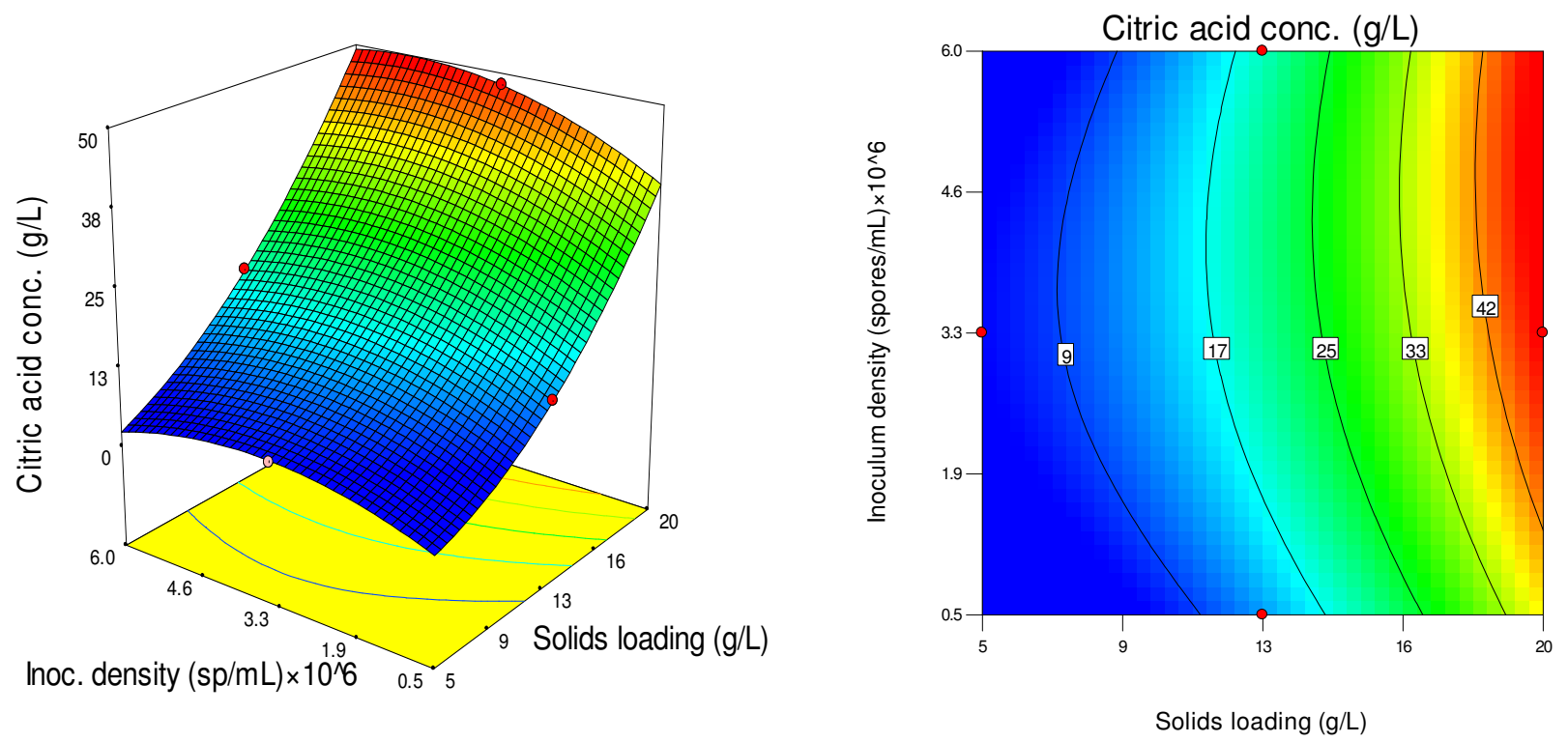

Figure 4: Response surface and corresponding contour plot showing the effects of inoculum density and solids loading on citric acid concentration

The final optimised conditions for the production citric acid as obtained from RSM were a solid loading of $20 \mathrm{~g} / \mathrm{L}, \mathrm{a} \mathrm{pH}$ of 8 and an inoculum density of $4.97 \times 10^{6}$ spores $/ \mathrm{mL}$. The statistical model was validated by comparing model predicted results with those of repeated experiments carried out at the optimised conditions. The mean of the results obtained from three replications was close to that predicted by the model thus showing validity.

\section{CONCLUSION}

Citric acid production from banana peels via solid state fermentation using Aspergillus nigerwas investigated in this study. A three-variable, three-level Box-Behnken design was used to study the simultaneous effect of solid loading, initial $\mathrm{pH}$ and inoculum density. A statistically significant model $(p<0.0001)$ was developed to describe the relationship between citric acid concentration and the chosen independent variables. The fermentation conditions were optimised using RSM. The statistical model showed a good fit with the experimental data 
$\left(\mathrm{R}^{2}=0.999\right)$ with a low standard deviation. High level of solid loading, low levels of $\mathrm{pH}$ and intermediate levels of inoculum density were favourable for citric acid production. Citric acid production was positively influenced by solid loading while the reverse was the case for initial $\mathrm{pH}$. The optimum values of solid loading, $\mathrm{pH}$ and inoculum density were $20 \mathrm{~g} / \mathrm{L}, 8$ and $4.97 \times 10^{6}$ spores $/ \mathrm{mL}$ respectively. Under these conditions, the citric acid concentration was obtained as $49.9 \mathrm{~g} / \mathrm{L}$.

\section{REFERENCES}

[1] Amenaghawon N.A., Osazuwa, O.U. and Okieimen, C.O. "Dynamic modelling and simulation of citric acid production from dilute acid hydrolysed corn starch using Aspergillus niger", Nigerian Journal of Technology, Vol. 33, Number 2, 2014, pp. 222-229.

[2] Amenaghawon, N.A., Oronsaye, J.E and Ogbeide, S.E. "Statistical Optimisation of Fermentation Conditions for Citric Acid Production from Pineapple Peels", Nigerian Journal of Technological Research, Vol. 9 Number 2 2014, pp. 20-26.

[3] Imandi, S.B., Bandaru, V.V.R., Somalanka, S.R., Bandaru, S.R. and Garapati, H.R. "Application of statistical experimental designs for the optimization of medium constituents for the production of citric acid from pineapple waste", Bioresource Technology, Vol. 99, Number 10, 2008, pp. 4445-4450.

[4] Kareem, S.O. and Rahman, R.A. "Utilization of banana peels for citric acid production by Aspergillus niger. Agriculture and Biology Journal of North America, Vol. 4, Number 4, 2013, pp. 384-387.

[5] Prado, F.C., Vandenberghe, L.P.S., Woiciechowski, A.L., Rodrigues-Leon, J.A. and Soccol, C.R. "Citric acid production by solid-state fermentation on a semipilot scale using different percentages of treated cassava bagasse", Brazilian Journal of Chemical Engineering, Vol. 22, Number 4, 2005, pp. 547-555.

[6] Gopinath, S.M., Puttaiah, E.T. and Narasimha Murthy, T.P. "Citric acid production by Aspergillusniger ETGP12, ETGP18 on solid state fermentation and effect of initial temperature on yield", International Journal of Pharma and Bio Sciences, Vol. 2, Number 4, 2011, 250-256.

[7] Amenaghawon, N.A, Areguamen, S.O., Agbroko, N.T., Ogbeide, S.E. and Okieimen, C.O. "Modelling and Statistical Optimisation of Citric Acid Production from Solid State Fermentation of Sugar Cane Bagasse using Aspergillus niger", International Journal of Sciences, Vol. 2, Number 3, 2013, pp. 56-62.

[8] Kumar, A. and Jain, V.K. "Solid state fermentation studies of citric acid production", African Journal of Biotechnology, Vol. 7, Number 5, 2008, pp. 644-650.
[9] Baei, M.S., Mahmoudi, M. and Yunesi, H. "A kinetic model for citric acid production from apple pomacby Aspergillusniger", African Journal of Biotechnology, Vol. 7, Number 19, 2008, pp. 3487-3489.

[10] Assadi, M.M. and Nikkhah, M. "Production of citric acid from date pulp by solid state fermentation", Journal of Agricultural Science and Technology, Vol. 4, Number 3, 2002, pp. 119-125.

[11] Roukas, T. "Citric acid production from carob pod by solid state fermentation", Enzyme and Microbial Technology, Vol. 24, 1999, pp. 54-59.

[12] Hang, Y.D. and Woodams, E.E. "Grape pomace a novel substrate for microbial production of citric acid", Biotechnology Letters, Vol. 7, 1985, pp. 253254.

[13] FAO. Food and Agriculture Organisation Statistics. Available from http://faostat.fao.org, 2010.

[14] Nagarajaiah, S.B. and Prakash, J. "Chemical composition and antioxidant potential of peels from three varieties of banana", Asian Journal of Food and Agro-Industry, Vol. 4, Number 1, 2011, pp. 3146.

[15] Emaga, T.H., Bindelle, J., Agneesens, R., Buldgen, A., Wathelet, B. and Paquot, M. "Ripening influences banana and plantain peels composition and energy content", Tropical Animal Health and Production, Vol. 43, Number 1, 2011, pp. 171-177.

[16] Anhwange, B.A., Ugye, T.J. and Nyiaatagher, T.D. "Chemical composition of Musa sapientum (banana) peels", Journal of Food Technology, Vol. 6, Number 6, 2008, pp. 263-266.

[17] Amenaghawon, N.A, Nwaru, K.I., Aisien, F.A., Ogbeide, S.E and Okieimen, C.O. Application of BoxBehnken Design for the Optimization of Citric Acid Production from Corn Starch Using Aspergillus niger, British Biotechnology Journal, Vol. 3, Number 3, 2013, pp. 236-245.

[18] Barrington, S. and Kim, J. W. (2008). "Response surface optimization of medium components for citric acid production by Aspergillus niger NRRL 567 grown in peat moss", Bioresource Technology, Vol. 99, Number 2, 2008, pp. 368-377.

[19] Fang, H., Zhao, C. and Song, X. "Optimization of enzymatic hydrolysis of steam-exploded corn stover by two approaches: Response surface methodology or using cellulase from mixed cultures of Trichodermareesei RUT-C30 and Aspergillus niger NL02", Bioresource Technology, Vol. 101, 2010, pp. 4111-4119.

[20] Montgomery, D.C. Design and Analysis of Experiments. 6. ed. New York: John Wiley \& Sons, Inc., 2005.

[21] Marrier, J.R. and Boulet, M. "Direct Determination of Citric Acid in Milk with an Improved Pyridine- 
Acetic Anhydride Method", Journal of Dairy Science, Vol. 41, Number 12, 1958, pp. 1683-1692.

[22] Amenaghawon, N.A., Ogbeide, S.E. and Okieimen, C.O. "Application of Statistical Experimental Design for the Optimisation of Dilute Sulphuric Acid Hydrolysis of Cassava Bagasse", ActaPolytechnicaHungarica, Vol. 11, Number 9, 2014, pp. 239-250.

[23] Amenaghawon, N.A., Osemwengie, S.O., Omoregbe, O. and Asogwa, U.J. "Application of experimental design method for the optimisation of xanthan gum production from pineapple peels using Xanthomonas campestris via submerged fermentation", Nigerian Journal of Technology, Vol. 34, Number 3, 2015, pp. 491-498.

[24] Qi, B., Chen, X., Shen, F. and Wan, Y. “Optimization of Enzymatic Hydrolysis of Wheat Straw Pretreated by Alkaline Peroxide Using Response Surface Methodology", Industrial and Engineering Chemistry Research, Vol. 48, 2009, pp. 7346-7353.

[25] Hou, X.J. and Chen, W. "Optimization of extraction process of crude polysaccharides from wild edible Bachu mushroom by response surface methodology", Carbohydrate Polymers, Vol. 72, 2008, pp. 67-74

[26] Cao, G., Ren, N., Wang, A., Lee, D.J., Guo, W., Liu, B., Feng, Y. and Zhao, Q. "Acid hydrolysis of corn stover for biohydrogen production using Thermoanaerobacteriumthermosaccharolyticum W16", International Journal of Hydrogen Energy, Vol. 34, 2009, pp. 7182-7188.

[27] Kim, J.K. “Optimization of Citric Acid Production by Aspergillus niger NRRL 567 in Various
Fermentation Systems. PhD Thesis. Quebec, Canada: McGill University, 2004.

[28] Al-Sheri M.A. and Mostafa, Y.S. "Citric acid production from date syrup using immobilized cells of Aspergillus niger", Biotechnology, Vol. 5, Number 4, 2006, pp. 461-465.

[29] Papagianni, M. "Advances in citric acid fermentation by Aspergillus niger: Biochemical aspects, membrane transport and modelling", Biotechnology Advances, Vol. 25, Number 3, 2007, pp. 244-263.

[30] Ali, S., Haq, I., Qadeer, M.A. and Iqbal, J. "Production of citric acid by Aspergillus niger using cane molasses in a stirred fermentor", Electronic Journal of Biotechnology, Vol. 5, Number 3, 2002, pp. 258271.

[31] Lee, J.H. and Yun, H.S. "Effect of temperature and $\mathrm{pH}$ on the production of citric acid from cheese whey by Aspergillus niger", Korean Journal of Mycology, Vol. 27, 1999, pp. 383-385.

[32] Nampoothiri, M.K., Baiju, T.V., Sandhya, C., Sabu, A., Szakacs, G. and Pandey, A. "Process optimization for antifungal chitinase production by Trichodermaharzianum", Process Biochemistry. Vol. 39, Number 11, 2004, pp. 1583-1590.

[33] Uyar, F. and Baysal, Z. "Production and optimization of process parameters for alkaline protease production by a newly isolated Bacillus sp. under solid state fermentation", Process Biochemistry, Vol. 39, Number 12, 2004, pp. 1893-1898.

[34] Adham, N. Z. "Attempts at improving citric acid fermentation by Aspergillus niger in beet-molasses medium", Bioresource Technology, Vol. 84, 2002, pp. $97-100$ 